\title{
Caffeine and Peripheral Blood Flow
}

Gary F. Merrill *, Harin Joshi

Department of Cell Biology and Neuroscience, Rutgers University, Piscataway, New Jersey USA

*Corresponding Author: Gary F. Merrill, Department of Cell Biology and Neuroscience, Rutgers University, Piscataway, New Jersey USA

Received date: February 05, 2020; Accepted date: February 13, 2020; Published date: February $18,2020$.

Citation: Gary F. Merrill (2020) Caffeine and Peripheral Blood Flow, J. Clinical Medical Reviews and Reports 2(2): DOI: $10.31579 / 2690-8794 / 009$

Copyright: () 2020 Gary F. Merrill, This is an open-access article distributed under the terms of The Creative Commons Attribution License, which permits unrestricted use, distribution, and reproduction in any medium, provided the original author and source are credited.

\section{Abstract Campus of Rutgers University, Piscataway, New Jersey. \\ Keywords: caffeine; peripheral blood flow; soft drinks; tea; coffee; energy drinks}

Caffeine is the drug of choice for adults of the world. It is commonly found in the favorite beverages they consume such as coffee, energy drinks, soft drinks and tea. The caffeine molecule is a decorative sculpture that helps visitors identify the recently-constructed Chemistry and Chemical Biology Building on the Busch

\section{Introduction}

Caffeine is the drug of choice for adults of the world. It is commonly found in the favorite beverages they consume such as coffee, energy drinks, soft drinks and tea. The caffeine molecule is a decorative sculpture that helps visitors identify the recently-constructed Chemistry and Chemical Biology Building on the Busch Campus of Rutgers University, Piscataway, New Jersey. Caffeine is ubiquitous and there is much in the lay press and non-biomedical scientific literature written about it (e.g. behavioral, dietetic, epidemiological, exercise ergogenics, nutritional, psychological and social). There have been few serious experimental investigations of caffeine's physiological and pathophysiological actions on important mammalian organs and organ systems. In our cardiovascular physiology research laboratory at Rutgers University, we are trying to bridge this gap.

\section{Methods}

Experimental subjects are mostly college student volunteers. Some come to the laboratory as part of a formal course they have enrolled in. Others come out of curiosity, and still others come to be of service to science. Subjects are both male and female. They come from multicultural backgrounds and are about 20-25 years of age. After interviews and informed consent, volunteers rest on an examination bed and are instrumented with physiological transducers including: thermocouples, electrocardiograms, blood pressure cuffs, cardiomicrophones, and plethysmographs. Several minutes later and when monitored variables (e.g. heart rate, blood pressure, blood flow) are in the steady state a first set of data is collected (baseline or control). Subsequently subjects consume caffeine either in the form of a tablet $(200 \mathrm{mg})$ or in their favorite beverage, usually coffee (150-400 mg, depending on espresso augmentations). Sixty minutes thereafter a second set of data is collected (experimental) and the two sets are compared statistically (experiments designed a priori).

\section{Results}

Under our experimental conditions the cardiovascular effects of caffeine appear within 15-30 minutes of consumption and are pronounced by 45 60 minutes. The most prominent effect observed to date is a marked reduction in peripheral blood flow. Related effects include attenuation of the local regulation of blood flow. For example, blood flow in an instrumented digit is unable to autoregulate in the presence of caffeine. Additionally, reactive hyperemia, another form of local control of blood flow, is abolished by caffeine. Finally, exercise or active hyperemia is also markedly attenuated by the drug. Thus, this methyl xanthine significantly impairs the human body's ability to regulate its peripheral blood supply. (see Figures 1, 2). 


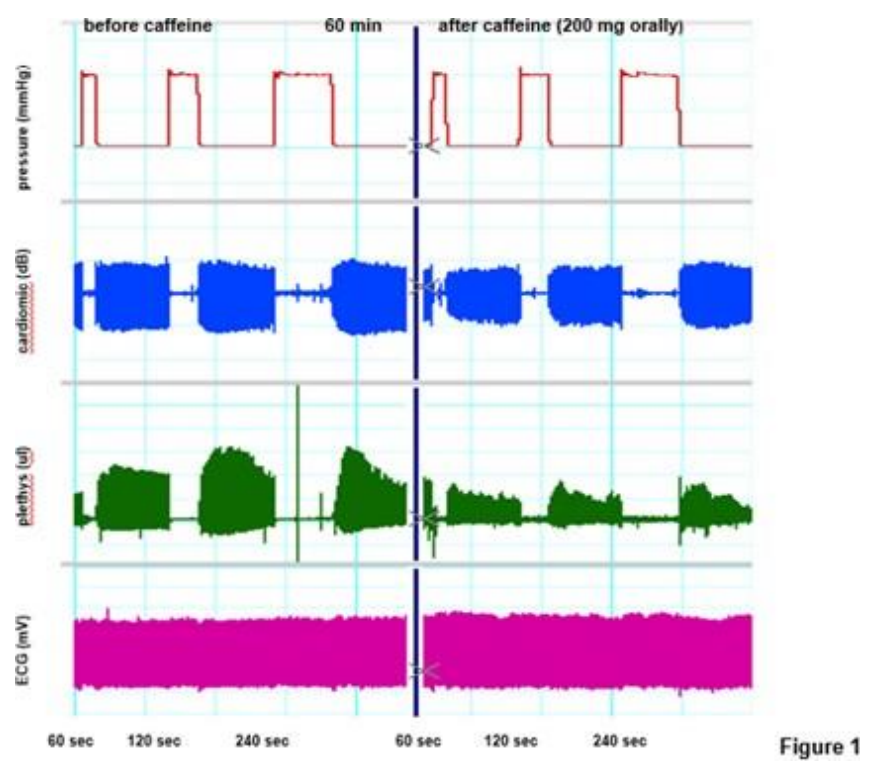

Figure 1: This figure illustrates the ability of caffeine ( $200 \mathrm{mg}$ orally) to attenuate reactive hyperemia (local regulation of peripheral blood flow) after periods of occlusion lasting 60, 120 and 240 seconds. See third row of data (green images) and compare images at left (absence of caffeine) with those at the right (60 min after an oral dose of $200 \mathrm{mg}$ caffeine).
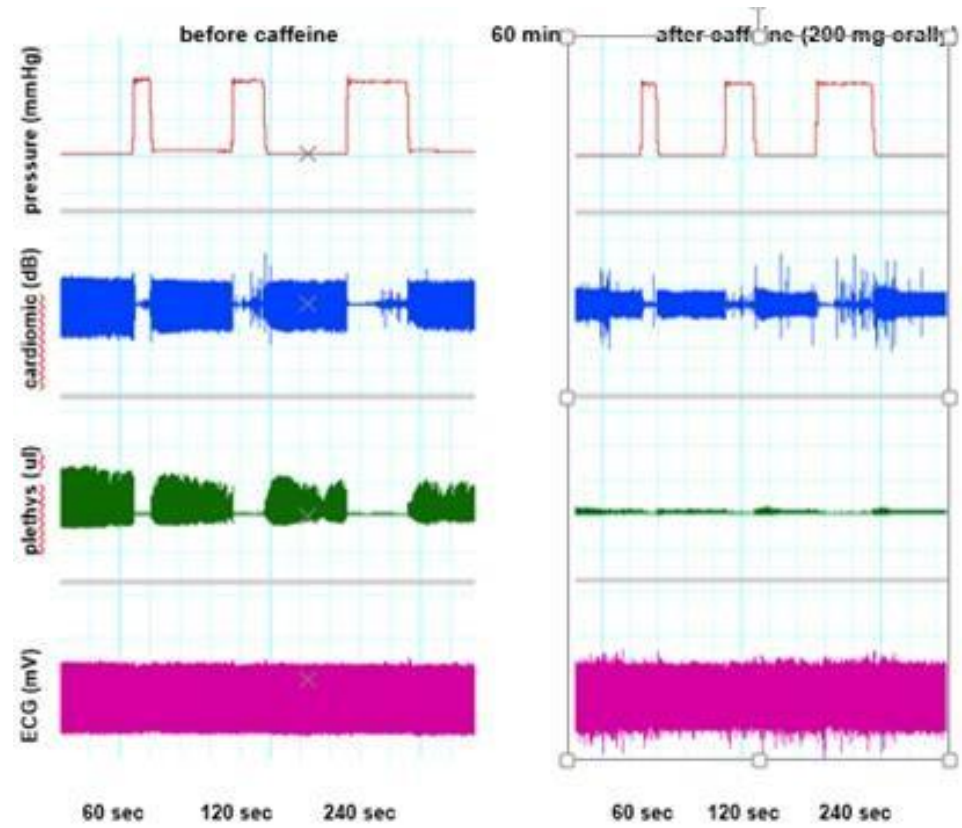

Figure 2

Figure 2: This figure demonstrates the ability of caffeine ( $200 \mathrm{mg}$ orally) to completely eliminate reactive hyperemia (local regulation of peripheral blood flow) after periods of arterial occlusion lasting 60, 120, and 240 seconds. See third row of data (green images) and compare images at left (absence of caffeine) with those at right (60 min after oral dose of $200 \mathrm{mg}$ caffeine).

While caffeine regularly and significantly increases systemic arterial blood pressure (vasoconstriction and increased peripheral vascular resistance), it does not appear to affect heart rate reliably; at least at the doses and experimental conditions we use.

\section{Discussion}

Blood flow regulation is one of the sin qua non of an unimpaired, healthy cardiovascular system. Local regulatory mechanisms of blood flow, such as pressure-flow autoregulation, reactive hyperemia, and active or exercise hyperemia, are key to the physiological function of organs and tissues that display them. A short list of such organs includes: brain, gut, heart, kidneys, skeletal muscle, skin and subcutaneous tissues [1.3]. In 
some cases, augmented nutrient supply during times of increased oxygen demand/reduced oxygen availability (e.g. hypoxia) can only be obtained through elevated blood flow (e.g. the heart and its coronary circulation). In such organs extra supplies of oxygen cannot be obtained through increased extraction. Therefore, being able to regulate blood flow locally is key to organ function and survival [4,7].

We are finding that caffeine, whether taken as a tablet or consumed in drinks such as coffee, consistently impairs the local regulation of peripheral blood flow $[8,10]$. We have found this in collegeage young adults but have not investigated any other demographic age group (e.g. children, aging adults). Although we have not yet investigated physiological mechanisms of the attenuation, we suspect a role for adenosine and its receptors $[11,16]$. Caffeine and other methyl xanthines recognize and bind to vascular adenosine receptors competitively $[4,15$, 17].

Adenosine and its receptors are distributed ubiquitously throughout the human body [18-20]. Its important vascular and regulatory functions have been reported since Robert Berne's initial discoveries in the early 1960s [21,22]. Before and during the 1970s many investigators, including the Merrill lab [17], were reporting competitive inhibition of adenosine's physiological properties by the methyl xanthines $[21,22]$. Thus, this mechanism of the caffeine-peripheral vascular interaction, specifically in the human cardiovascular system, needs further investigation. This is especially warranted considering the masses of people, young and old, rich and poor, male and female, educated and ignorant, who are addicted to caffeinated beverages. The need is amplified by the food and beverage industries recent business exploits, e.g. adding caffeine to chewing gum, candy, ice cream, yogurt, etc. In other words, the addictive properties of the drug are being promoted in much the same way that nicotine, tobacco and vaping have been.

A case in point---Consider the following possibility. A young man or young woman hears in a high school locker room that consuming caffeinated energy drinks (or taking caffeine tablets) before workouts/sport competitions 'boosts one's energy' and chances for success. In ignorance of the above cardiovascular effects and physiology in general they consume a large dose of caffeine, e.g. $500 \mathrm{mg}$. At the peak of their event the heart, brain, and muscles demand more oxygen. However, such organs might not get the needed oxygen from increased blood flow. This is because caffeine is blocking vascular adenosine receptors, specifically those on resistance arterioles, preventing needed vasodilation. Under worse-case conditions, i.e. increased myocardial oxygen demand without accompanying active hyperemia, myocardial ischemia and infarction are possibilities. Infarction can lead to ventricular fibrillation and sudden cardiac death; a sobering possibility for this young, under-educated and unsuspecting youth.

In conclusion caffeine is a potent vasoconstrictor that is able to reduce peripheral blood flow significantly. Caffeine inhibits the ability of peripheral tissues to regulate their blood supply (hence oxygen delivery) during pressure-flow autoregulation [23], reactive hyperemia (24), and active or exercise hyperemia (unpublished ongoing investigation). Under extreme conditions the compound is capable of causing sudden cardiac death by limiting coronary circulation and causing ventricular tachycardia and/or fibrillation [25]. More experimental investigation is needed on the physiology and pathophysiology of caffeine, its analogs (e.g. theophylline, theobromine), and caffeinated beverages in general.

\section{References}

1. Shepherd JT, Abboud FM.(1983) Handbook of Physiology, Section 2, The Cardiovascular System, volume III, Peripheral Circulation and Organ Blood Flow, part 2, American Physiological Society.
2. Geiger SR, Renkin EM, Michel CC.(1984) Handbook of Physiology, Section 2, The Cardiovascular System, volume IV, Microcirculation, part 2, American Physiological Society.

3. House SD, Johnson PC.(1986) Diameter and blood flow of skeletal muscle venules during local flow regulation. Am. J. Physiol. Heart. 250:H828-H837.

4. Wei HM, Kang YH, Merrill GF.(1989) Canine coronary vasodepressor responses to hypoxia are abolished by 8 phenyltheophylline. Am. J. Physiol. Heart. 257:H1043-H1048.

5. Wei HM, Kang YH, Merrill GF.(1988) Adenosine's role in the coronary vasodilation of global myocardial hypoxia: effects of adenosine deaminase. Am. J. Physiol.Heart. 254:H1004-H1009.

6. Merrill GF, Downey HF, Yonekura S, Watanabe N, Jones CE. (1988) Adenosine deaminase attenuates canine coronary vasodilation during regional nonischemic myocardial hypoxia. Cardiovas. Res. 22:345-350.

7. Downey HF, Merrill GF, Yonekura S, Watanabe N, Jones CE.(1988) Adenosine deaminase attenuates norepinephrineinduced coronary functional hyperemia. Am. J. Physiol. Heart, 254:H417-H424.

8. Merrill GF, Sharp, VA. (2018) Undesirable cardiovascular effects of hot drinks. Int'l Jou Clin Med Cases, 1(3):117-124.

9. Merrill GF, Costea DM, Sharp VA. (2019) Caffeine and reactive hyperemia. World J Cardiovas Dis. 9:437-448.

10. Merrill GF, Costea DM, Sharp VA.(2019) Caffeine and pressure flow autoregulation. World J Cardiovas Dis. 9:253-266,

11. Leone RJ Jr., Merrill GF. (995) Inhibition of myocardial adenosine deaminase and administration of adenosine intensify hypoxia-induced ventricular ectopy. Bas. Res. Cardiol. 90:234239.

12. O'Connor PJ, Merrill GF.(1995) Ventricular arrhythmias caused by repeat exposure to hypoxia are dependent on duration of reoxygenation. FASEB J. 9:387-391.

13. Leone RJ Jr, Friedrichs GS, Merrill GF.(1993) Adenosine deaminase and BWA1433U attenuate hypoxia-induced ventricular ectopy. J. Appl. Physiol. 74:1543-1548.

14. Friedrichs GS, Merrill GF. (1991) Adenosine deaminase and adenosine attenuate ventricular arrhythmias caused by norepinephrine. Am. J. Physiol. Heart. 260:H979-H984.

15. Wei HM, Friedrichs GS, Merrill GF.(1991) Route-dependent effects of 2-chloroadenosine and theophylline in isolated perfused guinea pig hearts. Cardiovas. Res. 25:529-536.

16. Kang YH, Wei HM, Merrill GF.(1990) Role of adenosine in catecholamine-induced coronary functional hyperemia. J. Cardiovas. Pharmacol. 15:940-946.

17. Merrill GF, Haddy FJ, Dabney JM.(1978) Adenosine, theophylline and perfusate $\mathrm{pH}$ in the isolated, perfused guinea pig heart. Circ. Res. 42:225-229.

18. Cronstein BN, Sitkovsky M.(2017) Adenosine and adenosine receptors in the pathogenesis and treatment of rheumatic diseases. Nat. Rev. Rheumatol. 13:41-51.

19. Chen JF, Zhang S, Zhou R, Lin Z, Cai X, et al (2017) Adenosine receptors and caffeine in retinopathy of prematurity. Mol. Aspects Med. 55:118-125.

20. Gessi S, Varani K, Merighi S, Ongini E, Borea PA. (2000) A2a adenosine receptors in human peripheral blood cells. Br. J. Pharmacol. 129:2-11.

21. Berne RM (1964) Regulation of coronary blood flow. Physiol. Rev. 44:1-29.

22. Feigl EO.(1983) Coronary physiology. Physiol. Rev. 63: 1-205.

23. Merrill GF, Costea DM, Sharp VA. (2019) Caffeine and pressure flow autoregulation. World J. Cardiovas. Dis. 9:253-266. 
24. Merrill GF, Costea DM, Sharp VA. Caffeine and reactive hyperemia. World J. Cardiovas. Dis. 9:437-448.
25. Jones AW.(2017) Review of caffeine-related fatalities along with postmortem blood concentrations in 51 poisoning deaths. J. Anal. Toxicol., 41:167-172.
This work is licensed under Creative

Commons Attribution 4.0 License

To Submit Your Article Click Here: Submit Manuscript

DOI: $10.31579 / 2690-8794 / 009$
Ready to submit your research? Choose Auctores and benefit from:

* fast, convenient online submission

* rigorous peer review by experienced research in your field

* rapid publication on acceptance

* authors retain copyrights

* unique DOI for all articles

* Immediate, unrestricted online access

At Auctores, research is always in progress.

Learn more www.auctoresonline.org/journals/clinical-medical-reviewsand-reports 